\title{
MUHTÂR ES-SEKAFÎ HAREKETINE DESTEK VEREN UNSURLAR
}

Groups Supporting the Mukhtār al-Thaqafi Movement

\section{Yasin KURNAZ}

Dr. Vaiz, Diyanet İşleri Başkanlığı Kadınhanı İlçe Müftülüğü, Konya, Türkiye

Dr., Presidency of Religious Affairs, Konya, Turkey

yasinkurnaz@windowslive.com | https://orcid.org/0000-0001-5930-8382

(i) Makale Bilgisi / Article Information:

Makale Türü / Article Type: Araştırma Makalesi / Research Article

Geliş Tarihi / Received: 28.05.2019

Kabul Tarihi / Accepted: 28.10.2019

Yayın Tarihi / Published: 31.12.2019

99 Atıf / Cite as: Kurnaz, Yasin. "Muhtâr es-Sekafî Hareketine Destek Veren Unsurlar". Mütefekkir 6/12 (2019): 471-488. https://doi.org/10.30523/mutefekkir.659193.

(C) Telif / Copyright: Published by Aksaray Üniversitesi İslami İlimler Fakültesi / Aksaray University Faculty of Islamic Education, 68100, Aksaray, Turkey. Tüm Hakları saklıdır / All rights reserved.

夗 İntihal / Plagiarism: Bu çalışma hakem değerlendirmesinden geçmiş, bir intihal yazılımı ile taranmıștır. İntihal yapılmadığı tespit edilmiștir. This article has gone through a peer review process and scanned via a plagiarism software. No plagiarism has been detected. 


\section{MUHTÂR ES-SEKAFÎ HAREKETINE DESTEK VEREN UNSURLAR}

Öz

Kerbelâ faciası, kendisinden sonra pek çok siyasî, sosyal ve askerî hareketin canlanmasına uygun bir zemin yaratmıştır. Muhtâr hareketi Kerbelâ faciasının bu anlamda başarıya ulaşan ilk ürünüdür denilebilir. Muhtâr önderliğinde iki seneye ulaşmayan bir ömre sahip olan söz konusu hareket, gücünü Kerbelâ'da yaşananların intikamını almak söyleminden almış ve taraftar kitlesini Hz. Hüseyin'in ismini sloganlaştırmak suretiyle toplamıștır. Muhtâr hareketi, Kûfe'deki Yemenî Arap kabileleri, Medâin halkı, mevâlî ve sosyoekonomik bakımdan zayıf kimselerden oluşan bir kitleye sahiptir. Bu kitleyle bir tarafta Emevî yönetimi, diğer tarafta Abdullah b. Zübeyr'le mücadele ederken aynı zamanda Kûfe halkının yerli Araplarından oluşan ileri gelenlerinin isyanını bastırmıştır. Özellikle Kûfe halkının gerçekleştirdiği bu isyan, çıkış noktasını Muhtâr hareketinde yer alanların kimliklerinden duydukları rahatsızlıktan almıştır. Kısa zamanda içerde ve dışarıda bu kadar düşman sahibi olan söz konusu hareketin kendisine nasıl taraftar bulduğu, söz konusu kitlenin kimlerden oluştuğu üzere bir fizibilite çalışması yapmak suretiyle anlaşılacaktır. Bu çalışma aynı zamanda Muhtâr hareketinin amaçlarının daha iyi anlaşılmasına da katkı sağlayacaktır.

Anahtar Kelimeler: İslâm Tarihi, Muhtâr es-Sekafî, Mevâlî, Ehl-i Beyt, Hz. Hüseyin.

\section{Groups Supporting the Mukhtār al-Thaqafĩ Movement}

Abstract

Karbala disaster formed a suitable basis for the revival of many successor political, social and military movements. It can be said that the Mukhtār Movement is the first product of the Karbala disaster that has succeeded in this sense. This movement, could not be able to reach two years under the leadership of Mukhtâr, has taken its power from the expression of taking revenge of the events that took place in Karbala and gathered its supporters by sloganizing the name of al-Hussain. Mukhtār movement consisted of a group from Yemeni Arab tribes in Kufa, the Medain people, mawali people and those consisting of socio-economically weaker people. While the Mukhtār with this group, struggled with Umayyad administration, on the one hand, Abdallah ibn Zubayr on the other, it also quashed the rebellion of the notables of Kufa people consisted of native Arabs. This rebellion, especially performed by the people of Kufa, took its start point from the disturbance of the identities included in the Mukhtār movement. It will be understood by the fact that this movement having so many internal and external enemies could be able to find supporters in such a short period of time by making a feasibility study about the said mass. This study will also contribute to a better understanding of the aims of the Mukhtār movement.

Keywords: Islamic History, Mukhtār al-Thaqafi, Mawali, Ahl al-Bayt, al-Ḥussain.

\section{GIIRIŞ}

Yezîd b. Muâviye'nin hilafete geçmesinden sonra Kûfe halkı Hz. Hüseyin'e yazdığı mektuplarla ona destek olacaklarını ve onu halife olarak görmek istediklerini belirtmişlerdir. Hz. Hüseyin bu mektuplardan aldığı destekle Medine'den yola çıkmış ancak Kûfe'ye ulaşmadan Kerbelâ denilen mevkide şehit edilmiştir. Yaşanan bu hadiseden yaklaşık beş sene sonra Kûfe'de önce Süleyman b. Surâd önderliğinde Tevvâbîn hareketi, 
hemen ardından da Muhtâr önderliğinde bir başka kıyam gerçekleşmiş ve ikisi de Hz. Hüseyin'in intikamını almayı amaçladıklarını söyleyerek taraftar toplamışlardır. Muhtâr, kıyamına Kûfe'de hayat vermiştir. Arap yarımadasının Güney Arapları, Kuzey Arapları ve Doğu Araplarının yaşadığı kentte, İranlılar, Suriyeliler, Çinliler, Bizanslılar, Necranlılar ve Medineliler bulunmaktadır. Bunlara mevâlî unsuru da eklenmelidir. ${ }^{1}$ Kûfe'de farklı kesimlerin bir arada yaşadığı bir hayat tecrübe edilmiştir. Kûfe, yaşanan sosyal-siyasal çalkantıların her birinde kendisini ifade edebilen farklılıkların bulunduğu kozmopolit bir şehirdir. Bu şehirde gerçekleşen Muhtâr hareketi, zaman içerisinde artan taraftar kitlesiyle yaklaşık iki sene hüküm sürmüștür. İlk dönemde Muhtâr'a bey'at edenlerin sayısının 3.8002-4.000 olduğu zikredilmektedir. ${ }^{3}$ Kûfe valilik konağının kuşatması esnasında ise 6.000 kişinin, üç gün Muhtâr'la birlikte beklediği bildirilmektedir. ${ }^{4}$ Dönemin valisi Abdullah b. Mutî‘ onların sayılarının az olduğunu vurgulamıştır. ${ }^{5}$ Kûfe yönetimini ele geçirdikten sonra Muhtâr'ın adamlarının sayısının 12.000'i geçtiği görülür. 6 Tüm bunlar Muhtâr hareketine katılanların sayısının şehrin nüfusuna oranla azınlıkta kaldığını göstermektedir.

Muhtâr hareketinde yer alan kesimleri bilmek, Kûfe'de çoğunluğa sahip olmamasına rağmen başarıya nasıl ulaştığı konusunda düşünce zenginliği kazandıracak, dönemin ve şehir halkının anlaşılmasına katkı sunacaktır. Bu çalışmada Muhtâr hareketinin taban kitlesi hakkında bilgiler sıralanmış ve böylece söz konusu hareketin daha iyi anlaşılmasına katkı sağlanmaya çalışılmıştır.

\section{MUHTÂR HAREKETINE DESTEK VEREN KÛFE'DEKI KABILLELER VE BU KABİLELERE BAĞLI KIŞIILERDEN BAZILARI}

Güney, Kuzey ve Doğu Arap kabilelerin bir arada yaşadığı Kûfe'de

1 Ziyâd b. Ebîh döneminde divana kayıtlı mukatile ve ailelerinin sayısına bakılarak 140.000'e ulaşan bir nüfustan bahsedilmektedir. Geniş bilgi için bk. Mehmet Mahfuz Söylemez, Bedevîlikten Hadarîliğe Kûfe (Ankara: Ankara Okulu Yayınları, 2015), 107-196.

2 Ebû Ca'fer Muhammed b. Cerîr et-Taberî, Târîhu't-taberî, Târîhu'r-rusûl ve'l-mülûk (Beyrut: Dâru't-Türâs, 1967/1387), 6: 23; İbnü'l-Esîr, İzzüddîn b. Ebi'l-Hasen Ali b. Ebi'l-Kerem Muhammed b. Muhammed el-Cezerî, el-Kâmil fít-târih, thk. Ömer Abdüsselâm Tedmürî (Beyrut: Dâru'l-Kütübi'l-Arabî, 1997/1417), 3: 297.

3 İbn Kesîr, Ebu'l-Fidâ İsmâîl b. Ömer, el-Bidâye ve'n-nihâye (Beyrut: Dâru'l-Fikr, 1986/1407), 8: 266.

4 Ebu'l-Abbas Ahmed b. Yahyâ b. Câbir el-Belâzürî, Ensâbü'l-eșrâf, thk. Süheyl Zekkâr-Riyad Ziriklî (Beyrut: Dâru'l-Fikr 1996/1417), 6: 394-395; Taberî, Târîh, 6: 33; İbnü'l-Esîr, elKâmil, 3: 301; İbn Kesîr, el-Bidâye, 8: 268. İbnü'l-Esîr, Muhtâr'la birlikte çarpışmaya girenlerin sayısını 3.500 olarak kaydeder. Bk. İbnü'l-Esîr, el-Kâmil, 3: 301.

5 Taberî, Târîh, 6: 28. Dîneverî ilk dönemlerde 7.000 rakamını vermektedir. Bk. Ebû Hanîfe Ahmed b. Dâvûd ed-Dîneverî, el-Ahbâru't-tivâl, thk. Abdülmün'im Âmir (Kahire: Dâru İhyâi Kütübi'l-Arabî, 1960/), 291. Bağdâdî bu sayıyı mübalağalı bulmaktadır. Ebû Mansûr Abdülkâhir b. Tâhir b. Muhammed et-Temîmî el-Bağdâdî, el-Fark beyne'l-fırak ve beyâni'lfirkati'n-nâciye (Beyrut: Dâru'l-Âfâki'l-Cedîde, 1977/1397), 32.

6 Belâzürî, Ensâb, 6: 391; Taberî, Târîh, 6: 23; İbnü’l-Esîr, el-Kâmil, 3: 297. 
Muhtâr hareketine destek veren kabilelerin genel itibariyle Yemenî yani Güneyli oldukları göze çarpmaktadır.7 Muhtâr hareketine bakıldığında temelde güç kaynağının Hemdân kabilesi olduğu dikkat çekmektedir. Hemdân kabilesi Hz. Ali taraftarlığı ile bilinmektedir.8 Kerbelâ'da Hz. Hüseyin'e yardım etmek istemişler hatta kabileden bazı kimseler Hz. Hüseyin'le birlikte șehit olmuşlardır. ${ }^{9}$ Şehirde sözü geçen bir kabiledir. ${ }^{10} \mathrm{Hem}$ dân kabilesinin birçok kolu vardır. Bunlardan Şâkir, Şibâm başta olmak üzere Nehd,11 Harîf, Sevr Muhtâr hareketinde en aktif rol oynayan kabilelerdir. Emevîler 66/686'da Hicaz'daki Abdullah b. Zübeyr'in hâkimiyetine son vermek için harekete geçtiğinde Muhtâr, İbn Zübeyr'e yardım güçleri göndermiştir. Muhtâr'ın gönderdiği bu ordunun başındaki Şurahbîl b. Vers, Havșeb el-Bürsümî, Kays b. Tahfe en-Nehdî, Abdullah b. Kâmil eşŞâkirî, Saîd b. Münkîz es-Sevrî, Abdurrahman b. Şureyh eş-Şibâmî12 çeşitli kollardan olmak üzere hepsi esasında Hemdân kabilesindendir.

Kûfe'de yaşayan Becîle kabilesi de Muhtâr hareketinde yer almış Yemenî bir kabile olup Hz. Ali taraftarlığı ile bilinmektedir. Hatta Sıffîn'de Hz. Ali saflarında savaşmıştır. Becîle ile kardeşlik bağları bulunan Has'am ve Becîle'nin bir kolu olan Ahmes'de Muhtâr hareketine destek vermiştir. ${ }^{13}$ Ahmer b. Şumeyt el-Becelî, Rifâa' b. Şeddât el-Becelî, Abdullah b. Kurâd el-Has'amî ${ }^{14}$ bu kabilelere ait isimlerden sadece bir kaçıdır. ${ }^{15}$

Kûfe'de Muhtâr hareketine katılan Yemenî kabilelerden bir diğeri olan Mezhîc, ilk zamanlardan beri Hz. Ali saflarında yer almakla birlikte Kerbelâ'da Ömer b. Sa'd'ın ordusunda Hz. Hüseyin'e karşı savaşmış16 ancak daha sonra pişman olarak Tevvâbîn hareketine, Tevvâbîn hareketinin

7 Dîneverî, el-Ahbâru't-tıvâl, 291; Belâzürî, Ensâb, 6: 419-421; Taberî, Târîh, 6: 9, 17, 28-29, $35,41,49-51,57,72-75,83,422-423$.

8 İbn Hazm, Ebû Muhammed Ali b. Ahmed b. Saîd el-Endelüsî el-Kurtubî, Cemheretü ensâbi'lArab, thk. Komisyon (Beyrut: Dâru'l-Kütübi'l-i̇lmiyye, 1983/1403), 394-395. Muhtâr'ın Kûfe'yi ele geçirmesi esnasında yaşananlar hakkında Abdullah b. Hemmâm es-Selûlî'nin şiirinde Hemdân, Mezhîc ve Esed kabileleri zikredilmektedir. Bunlardan Hemdân ve Mezhîc Yemenî kabilelerdir. Bk. Dîneverî, el-Ahbâru't-tıvâl, 291.

9 Ebû Muhammed Lisânü'l-Yemen el-Hasen b. Ahmed b. Ya'kub el-Hemdânî, el-İklîl (b.y. y.y. t.s.), 23-24, 27.

10 Yezîd b. Muâviye vefat ettikten sonra Kûfe valisi olması için Ömer b. Sa‘d b. Ebî Vakkâs vali seçilmek istenmiș ancak Hemdân kabilesinin itirazları ile Abdullah b. Zübeyr yanlısı Âmir b. Mes'ûd vali olmuştu. Bk. Taberî, Târîh, 5: 524. Bu hadise Hemdân'ın şehirdeki nüfuzunu göstermektedir.

11 Özellikle Nehd kabîlesi Muhtâr hareketinin her aşamasında yer almış ve en aktif rolü üslenmiștir. Bk. Taberî, Târîh, 6: 17, 35, 49-51, 57, 83.

12 Belâzürî, Ensâb, 6: 419-421; Taberî, Târîh, 6: 72-75; İbnü'l-Esîr, el-Kâmil, 3: 317-318; İbn Kesîr, el-Bidâye, 8: 276-277.

13 Irak topraklarına yerleșen bu kabile Hz. Ali taraftarı olup Sıffîn'de Hz. Ali saflarında savaşmıștır. Bk. Taberî, Târîh, 5: 25-27.

14 Taberî, Târîh, 6: 6-9.

15 Abdullah İbn Hemmam es-Selûlî, kasidesinde Muhtâr'a katılan kiși ve kabileler hakkında bilgi vermektedir. Bk. Taberî, Târîh, 6: 35-36.

16 Taberî, Târîh, 6: 389-393, 422,468 
mağlubiyetinden sonra da Muhtâr'a katılmışlardır. ${ }^{17}$ Tay kabilesi de Yemenî kabilelerden olup Hz. Ali taraftarlığı ile bilinmektedir. Muhtâr hareketine destek vermiştir. ${ }^{18}$ Muhtâr'a destek veren kabilelerden Müzeyne, Ahmes ve Bârık kabilelerini birlikte zikretmek gerekir. Zira bu üç kabile yerleşke itibariyle birbirlerine komşudur. ${ }^{19}$ Bu üç kabilenin Muhtâr hareketinde önemli bir yer tuttuğu görülmektedir. ${ }^{20}$ Kinde kabilesi Yemenî bir kabile olmakla birlikte Muhtâr hareketinde bütün bireyleriyle yer almamıştır. Kinde kabilesinden Ubeyde b. Amr el-Beddî, İsmail b. Kesîr, el-Esved b. Kurâd el-Kindî, Abdurrahman b. Hucr b. Adiyy el-Kindî bu isimlerden bazılarıdır. ${ }^{21}$ Bununla birlikte Kinde kabilesinden Muhtâr hareketine karşı çıkanların etkinliği ve sayısı daha fazladır. Eş'as b. Kays el-Kindî ve oğlu Muhammed b. Eş'âs Kerbelâ'da Ubeydullah b. Ziyâd'ın tarafında yer almıș ve Kays b. el-Eş'as komutanlık yapmıștır. ${ }^{22}$ Muhtâr'a isyan eden kabilelerden birisi olmuş hatta Mus'ab'ın zaferiyle sonuçlanan Muhtâr'la girişilen harpte, Mus'ab tarafını tutmuştur. Esir edilen Muhtâr taraftarlarının idam kararlarının çıkmasında Mus'ab'a baskı uygulayarak onların öldürülmesini sağlayan en etkin kabile Kinde'dir. ${ }^{23}$ Ezd kabilesi de Ubeydullah b. Ziyâd'ın ordusunda Kerbelâ'ya katılmasıyla bilinmekteyken ${ }^{24}$ içlerinden bazı kimselerin Muhtâr hareketinde yer aldığı görülmektedir. Humeyd b. Müslim, ${ }^{25}$ Süfyân b. Yezîd ${ }^{26}$ gibi birkaç isim sırlanabilir.

Şeyban ve Kudâa kabileleri de Muhtâr'a destek vermiş başka Yemenî kabileler olup Nu'mân b. Sahbân ${ }^{27}$ ve Abdullah b. Damra bu kabilelerin kollarındandır. ${ }^{28}$ Şehirde çok fazla bir nüfuza sahip değillerdir. ${ }^{29} E$ Eşar ka- $^{\prime}$ bilesi de Muhtâr kıyamına katılmıştır. Örneğin es-Sâib b. Mâlik el-Eş'arî bu kabileden olup Muhtâr'a, o henüz hapiste iken bey'at etmiş ve kıyamda

\footnotetext{
Taberî, Târîh, 6: 422-423

18 Ömer Rizâ Kehhâle, Mu'cemü kabâ'ili'l-Arabi'l-kadîme ve'l-hadîse (Beyrut: Müessesetü'rRisâle 1994/1414) II: 690-692.

19 Taberî, Târîh, 6: 28.

20 Taberî, Târîh, 6: 28-29.

21 Belâzürî, Ensâb, 6: 379-380; Taberî, Târîh, 5: 578-580.

22 Dîneverî, el-Ahbâru't-tıvâl, 259.

23 Belâzürî, Ensâb, 6: 441-443; Taberî, Târîh, 6: 108-109; İbn A'sem, Ebû Muhammed, Ahmed b. Muhammed b. Ali el-Kûfî, el-Fütûh, thk. Ali Șînî (Beyrut: Dâru'l-Edvâ, 1991/1411), 6: 292293; İbnü'l-Esîr, el-Kâmil, 3: 336-337; Nüveyrî, Şihâbüddîn Ahmed b. Abdilvehhâb b. Muhammed b. Abdiddâim el-Kurașî, Nihâyetü'l-ereb fî fünûni'l-edeb (Kahire: Dâru'l-Kütübi ve'l-Vesâiki'l-Kavmî, 2002/1423), 11: 49.

24 Dîneverî, el-Ahbâru't-tıvâl, 259.

25 Belâzürî, Ensâb, 6: 382; Taberî, Târîh, 6: 9; İbnü'l-Cevzî, Cemâlüddîn Ebu'l-Ferec Abdurrahmân b. Ali b. Muhammed, el-Muntazam fî târîhi'l-ümem ve'l-mülûk, thk. Muhammed Abdülkādir Atâ ve Mustafâ Abdülkādir Atâ (Beyrut: Dâru'l-Kütübi'l-İlmiyye 1992/1412), 6: 52.

26 Taberî, Târîh, 6: 87.

27 Taberî, Târîh, 6: 50.

28 Taberî, Târîh, 6: 41.

29 Söylemez, Kûfe'nin Siyasi Tarihi, 131.
} 
aktif görev almıştır. ${ }^{30}$

Muhtâr hareketinin içerisinde yer alan Arap yarımadasının kuzey kabilelerinden isimlerle de karşılaşılmaktadır. Esed kabilesinden Yezîd b. Enes, Verkâ b. Âzib el-Esedî, Abdullah b. Verkâ el-Esedî bunlardandır. ${ }^{31}$ Bir diğer Kuzey bölgesi kabilelerinde Kays-Aylân'dan bazı fertleri Muhtâr hareketi içerisinde görmekteyiz. Muhtâr Kays-Aylân'ın bir kolu olan Sakîf kabilesindendir. Zâide b. Kudâme, Abdurrahman b. Ebî Umeyr Muhtâr'ın kabilesinden olup Muhtâr hareketine katılan ender isimlerdendir. ${ }^{32}$ Sakîf kabilesinden genel anlamda bir destek bulamayan Muhtâr, kendi kabilesinden olan bu kişilerin bireysel kararları neticesinde yanında yer almasına tanık olmuştur. Bununla birlikte kendisine destek olması için kendi kabilesine değil Yemenî kabilelere dayanmıștır. Abbas b. Ca'de el-Cedelî, Kays-Aylân'ın bir kolu olan Cedîle kabilesindendir. ${ }^{33}$ Kays-Aylân'ın bir diğer kolu olan Fezâre kabilesinden Yezîd b. Necebe, Müseyyeb b. Necebe el-Fezârî isimler göze çarpar. ${ }^{34}$ Aynı zamanda Muhtâr'ın eşlerinden birisi de Fezâre kabilesindendir. Muhtâr'ın kayınpederi Muâviye'nin valilerindendir. Azledilmesine kızarak kızını Hz. Ali taraftarlığı ile bilinen Muhtâr'la evlendirmiş ve onunla ilişkilerini kuvvetlendirmeyi amaçlamıştır. ${ }^{35}$ Kuzey Arap kabilelerinden birisi olan Cüşem'den Abdullah b. Şeddad elCüșemî Muhtâr hareketine destek veren isimlerdendir. ${ }^{36}$

$\mathrm{Bu}$ isimler nezdinde sıralanan bilgilerden bazı sonuçlar dikkat çekmektedir. Muhtâr kendisi Sakîf kabilesinden olmasına rağmen gücünü Yemenî kabilelerden almıştır. Kuzey Araplarından ise katılımlar genelde bireysel olarak gerçekleşmiştir. Onun Sakîf'ten olmasına rağmen Yemenî kabilelerle birlikte olup huruc etmesi, gerçekleştirmiş olduğu kıyamını kişiselleștirdiği yorumunu ${ }^{37}$ haklı çıkarır niteliktedir. Yemenî kabilelerin kendilerine liderlik edecek kimsenin Kuzey Arap kabilelerinden Sakîfli bir kimse olmasına rıza göstermeleri ise Muhtâr'ın kendisini Muhammed

30 Taberî, Târîh, 6: 9.

31 Taberî, Târîh, 6: 41.

32 Belâzürî, Ensâb, 6: 376-377; Taberî, Târîh, 5: 570; İbn Asâkir, Ebu'l-Kâsım Ali b. Hasen b. Hibetullâh b. Hüseyn, Târîhu Dımeșk, thk. Amr b. Ğarâme el-Amrî (Beyrut: Dâru'l-Fikr, 1995/1415), 18: 295-296.

33 Taberî, Târîh, 5: 369.

34 Belâzürî, Ensâb, 6: 367-368; Taberî, Târîh, 5: 562-563, 580-581; İbnü'l-Esîr, el-Kâmil, 3: 252253.

35 Taberî, Târîh, 6: 66; Bünyamin Erul, "Semûre b. Cündeb", DİA (İstanbul: TDV Yayınları, 2009) 36: 501-502. Bütün Fezâre kabilesinin Muhtâr saflarında yer aldığını söyleyemeyiz. Örneğin Esmâ b. Hârice el-Fezârî, Muhtâr'ın emri üzere Kerbelâ'da Hz. Hüseyin'e karşı savaşan bir kimse olması hasebiyle Muhtâr'ın emri üzere hakkında infazı çıkarılmış bir kimsedir. Yakalanamadığı için evinin yıkılması ile yetinilmiștir. Bk. Belâzürî, Ensâb, 6: 410411; İbn A'sem, el-Fütûh, 6: 254.

36 Taberî, Târîh, 6: 9; İbn Kesîr, el-Bidâye, 8: 265.

37 Mehmet Bahaüddin Varol, Siyasallaşma Sürecinde Ehl-i Beyt (Konya: Yediveren Yayınlarl, 2004), 188. 
b. Hanefiyye'nin veziri olarak göstermesine ${ }^{38}$ bağlanabilir. Ayrıca Süleyman b. Surâd'ın Yemenî bir kabile olan Huzâa'dan olması hatırda tutulmalıdır. Muhtâr'ın kendi taraftarlarını Yemenî bir lider olan Süleyman b. Surâd'a muhalefet içerisinde toplaması, Tevvâbîn hareketinin hezimetinden sonra kendisinin tek lider olarak kalması, onun Kuzey Araplarından olması cihetinden yapılacak olası eleştirilerin önünü kesmiş olmalıdır.

Muhtâr hareketinde yer alan bu kabilelerden bazıları birbirleriyle çok yakın komşuluk ilişkisi içerisindedir. Örneğin Müzeyne-Ahmes-Bârık kabileleri şehirde aynı yerde yaşamaktadırlar. ${ }^{39} \mathrm{Bu}$ durumun, onların birlikte hareket etmelerini sağlamış olması mümkündür. Has'am ve Becîle kabilelerinin kardeş kabileler, ${ }^{40}$ Mezhic ve Hemdân'ın müttefik olmaları ${ }^{41}$ onların siyasi hayatta birlikte yer almasını sağlamıștır.

Yine kabilelerin taraf tutarken birden fazla siyasî gerekçenin etkisinde kaldığı görülmektedir. Örneğin Becîle ile Kelb kabilesi arasında cahiliye döneminden beri süre gelen düșmanlıklar, bu iki kabilenin HâșimîEmevî çekişmesinde karşı taraflarda yer almasına neden olmuştur. ${ }^{42}$ Yemenî olan Ezd kabilesinden Muhtâr hareketine katılanın az olmasının en önemli sebebi, onların cahiliye döneminde Has'am kabilesi ile savaşmış olmasıdır denilebilir. ${ }^{43}$ Kabilelere bakıldığında birçoğunun Kerbelâ hadisesinden daha önceleri Emevî yönetim ve siyaseti ile mesafeli olduklarını görürüz. Bu durum onların Kerbelâ'nın intikamını almak söylemini konjonktürel slogan olarak kullandıklarını akla getirmektedir. Neticede Muhtâr hareketinde yer alan kesimlerin birden fazla siyasî gerekçe ile pozisyon aldıkları anlaşılmaktadır.

Muhtâr hareketine katılanlardan İbrâhim b. Eșter, Abdurrahman b. Şureyh eş-Şibâmî, Ebû'l-Kalûs eş-Şibâmî gibi bazı kişiler, kabile lideri yahut kabilesinde sözü geçen kimselerdir. Ayrıca Ebû't-Tufeyl Âmir b. Vâsile, Ebû Osman en-Nehdî gibi Hz. Ali taraftarlı̆̆ı ile bilinen ve Rifâa' b. Şeddâd el-Fityânî gibi Tevvâbîn'den hayatta kalan kimseler vardır. Sözü geçen isimler hakkında daha fazla bilgi sahibi olmak için İbrâhim b. Eşter'i Muhtâr saflarında savaşmak için ikna etmeye çalışan heyetteki bireyleri Şa'bî’nin nasıl tanımladığına bakmak gerekmektedir.

Rivayetlere göre 66/686 yılında Kûfe'yi ele geçirmek üzere harekete geçen Muhtâr, adamlarının da telkinleri ile İbrâhim b. Eşter'i kendi saflarında savaşmaya ikna etmek üzere harekete geçmiștir. Onu Muhammed

38 Belâzürî, Ensâb, 6: 380; Taberî, Târîh, 5: 580.

39 Taberî, Târîh, 6: 28.

40 Alûsî, Ebu'l-Meâli Cemâleddin Mahmûd Şükrî, Bulûgu'l-ereb fî ma'rifeti ahvâl'l-Arab, thk. Muhammed Behcet el-Eserî (Mısır: Dâru'l-Kütübi'l-Mısrî 2012) 2: 72.

41 Kehhâle, Mu'cemü kabâ'ili'l-Arabi'l-kadîme ve'l-hadîse, 1: 306.

42 Alûsî, Bulûgu'l-ereb fî ma'rifeti ahvâli'l-Arab, 1: 303; Söylemez, Kûfe'nin Siyasî Târihi, 110.

43 Reckondorf, "Ezd”, IA (İstanbul: MEB Basımevi, 1987) 4: 430; Söylemez, Kûfe'nin Siyasî Târihi, 116-117. 
b. Hanefiyye'nin yazdığını iddia ettiği bir mektupla kendi hareketine davet etmiştir. Bu mektubun Muhammed b. Hanefiyye'den geldiğine Muhtâr'la birlikte bulunan heyetteki herkes şahitlik etmiştir. Ancak yine de İbrâhim b. Eşter bu mektubun Muhammed b. Hanefiyye'den gelip gelmediğini araștırmak üzere harekete geçmiștir. Şa'bî̀ye bu durumu sorduğunda Şa'bî:

-Bu şahitler kurrâdandır. Memleketin sözü en dinlenen yaşlıları ve Arap süvarileridir. Ben şimdiye kadar onların ağzından doğru sözden başka bir söz duymadım, demiştir. ${ }^{44}$

Muhtâr kendi adamları hakkında Allah'ın Şurtaları ${ }^{45}$ demektedir. Ancak bu ifade onlara ait özel bir vasıftan dolayı niteliksel bir yaklaşımdan ziyade Hz. Hüseyin'in intikamını almak arzularının kendilerinin bu kıyamını cihat olarak tanımlamalarına neden olmasından kaynaklı olduğu yorumu yapılmaktadır. ${ }^{46}$

\section{MEVÂLÎ'NIN MUHTÂR HAREKETINDEKİ YERİ}

Muhtâr hareketinde yer alan unsurlardan bir tanesi de mevâlîdir. Mevâlî kısaca Arap olmayan Müslüman halklar olarak tanımlanmaktadır. ${ }^{47}$ Mevâlî'nin önemli bir kısmına el-Hamrâ denilmektedir. ${ }^{48}$ Sayılarının ilk zamanlarda az olduğu anlaşılmaktadır. Zira Muhtâr'ın Kûfe'yi ele geçirdiği gece dönemin valisi Abdullah b. Mutî‘ adamlarına yaptı̆̆ı son konuşmasında mevâlînin sayısının az olduğuna işaret etmiștir. ${ }^{49}$ Ancak bu sayının gün geçtikçe arttığı görülmüştür. Bunun sebebi şehrin ele geçirilmesinden sonra Muhtâr'ın ilk yaptığı konuşmasında kendisine katılacak bütün kölelerin azat edileceğini söylemesi olmalıdır. ${ }^{50}$ Sadece mevâlîden oluşan bir de atlı birlik oluşturduğu kaydedilmektedir. ${ }^{51}$ Şurta teşkilatının başına kendisi de bir mevâlî olan Ebû Amra Keysan'ı ataması mevâlî sayısının artmasının neticesidir. ${ }^{52}$ Dîneverî'nin verdiği 20.000 sayısı ise

44 Belâzürî, Ensâb, 6: 385-386; Taberî, Târîh, 6: 16-18; İbn A'sem, el-Fütûh, 6: 230; İbn Miskeveyh, Ebû Alî Ahmed b. Muhammed b. Ya'kūb el-Hâzin, Tecâribü'l-ümem ve teâkibü'lhimem, thk. Ebu'l-Kâsım İmâmî (İran: Serveş, 2000), 2: 144-146; İbnü'l-Esîr, el-Kâmil, 3: 293-294.

45 Taberî, Târîh, 6: 92.

46 Hind Gassân Ebu'ş-Şa'r, Hareketü'l-Muhtâr b. Ebî Ubeyd es-Sekafî fìll-Kûfe (Amman: Câmiatü'l-Ürdüniyye, 1983), 228.

47 Ebu'l-Fazl Cemâlüddîn Muhammed b. Mükerrem b. Ali, Lisânü'l-mîzân (Beyrut: Dâr Sâdır 1414) 15: 408-409; Adnan Demircan, İslâm Tarihinin İlk Döneminde Arap-Mevali İlişkisi (İstanbul: Beyan Yayıncılık, 2015), 16-17; İsmail Yiğit, "Mevâlı̂”, DİA (Ankara: TDV Yayıncılık, 2004), 29: 424-426.

48 Dîneverî, el-Ahbâru't-tıvâl, 288.

49 Taberî, 6: 28-29.

50 Belâzürî, Ensâb, 6: 448.

51 Belâzürî, Ensâb, 6: 429-430; Taberî, Târîh, 6: 95.

52 Taberî, Târîh, 6: 33; İbnü'l-Esîr, el-Kâmil, 3: 301. 
aşağıda takdim edilen bilgilerden den anlaşılacağı üzere mübalağalı durmaktadır. ${ }^{53}$

Muhtâr hareketindeki mevâlî sayısını doğrudan belirten rivayetlerle neredeyse karşılaşılmamaktadır. 66/868'da Emevîler karşısında Abdullah b. Zübeyr'e yardım etmek üzere sevkettiği Şurahbîl b. Vers'in önderliğinde Hicâz'a giden 3.000 kişilik ordudaki 2300 kişinin mevâlî olduğu rivayet edilmiștir ve bunların çoğu öldürülmüștür. ${ }^{54}$ Bunun dıșındaki askerî yapılanmalarda mevâlînin sayısını tam olarak belirtmek zordur. Örnek vermek gerekirse; 66/686 yılında Yezîd b. Enes önderliğinde Emevî birlikleri ile karşılaşan orduda ve aynı yılda İbrâhim b. Eşter önderliğinde Emevî güçleri ile karşılaşmak üzere hareket eden ordudaki mevâlînin sayısından bahsedilmemektedir. Bu seferlerde mevâlî, piyade olan diğer Arap askerlerle birliktedir. Ancak hareketin ilerleyen aşamalarında bu durum değişmeye başlamıştır. Örneğin 67/687'deki el-Mezâr savaşında sadece mevâlîden oluşan bir bölük asker bulunmaktadır. Liderleri de yine bir mevâlî olan Ebû Amra Keysân'dır. Bu bölüğün büyük çoğunluğu adı geçen savaşta yok edilmiştir. Kalan az bir kısım ise çöle kaçmıştır. ${ }^{55}$

Muhtâr'ın Kûfe iktidarının ilk günlerinde eşrâf ile olan yakın münasebetleri56 mevâlî de yankı bulmuştur. Kıyamın başarıya ulaşmasından önce Arap olmayan unsurlardan önemli ölçüde destek bulan ve ezilmişlerin haklarını savunacağına yönelik söylemleriyle bu desteğin artmasını sağlayan Muhtâr'ın, şehrin yönetimini ele alınca eşrafla daha sık temas içerisinde olması kendi taraftarlarında endişe uyandırmıştır. Muhtâr'ın eşrâftan bazıları ile konuşma yaptığı bir esnada mevâlîden birisi Ebû Amra Keysân'a gelerek, Muhtâr'ın yaptığı konuşmasının çoğu bölümlerini mevâlîye doğru değil de Eşrâf'a yönelerek icra etmiş olmasını eleştirmiştir. Bundan haberdar olan Muhtâr, Ebû Amra'ya: "Eşrâf ile olan yakınlığım sizi endişelendirmesin. Çünkü ben sizdenim, sizler bendensiniz," demiştir. Muhtâr sadece bu sözüyle mevâlînin kaygılarını bastıramayacağını düşündüğü için konuşması esnasında ve muhtemelen yine eşrâfa dönerek: "Muhakkak bizler günahkârlardan intikam alıcılarız" (es-Secde 32/22 ) âyetini okumuştur. Bunun üzerine mevâlî kendi aralarında:

-Müjde! Muhtâr bu ayeti okumak suretiyle eşrâfa: "Vallahi siz (Ehl-i

53 Dîneverî, el-Ahbâru't-tıvâl, 288.

54 Belâzürî, Ensâb, 6: 419-421; Taberî, Târîh, 6: 72-75.

55 Belâzürî, Ensâb, 6: 430-431; Taberî, Târîh, 6: 95-97; İbn Miskeveyh, Tecâribü'l-ümem, 2: 200; İbnü'l-Esîr, el-Kâmil, 3: 332. El-Mezâr savașı Abdullah b. Zübeyr'e bağlı Basra valisi Mus'ab b. Zübeyr ile Muhtâr arasında 67/687'de gerçekleșmiș ve Mus'ab b. Zübeyr kuvvetlerinin galibiyetiyle sonuçlanmıș bir savaștır. Geniș bilgi için bk. Belâzürî, Ensâb, 6: 430-431; Taberî, Târîh, 6: 95-97.

56 Belâzürî, Ensâb, 6: 395; Taberî, Târîh, 6: 33; İbnü'l-Esîr, el-Kâmil, 3: 301; İbn Kesîr, el-Bidâye 8: 268. 
Beyt'in) kanını döktünüz" demektedir, sözleriyle sevinmişlerdir. ${ }^{57}$ Muhtâr'ı böyle bir davranışa iten saik mevâlî desteğini kaybetmeme çabasıdır. Mevâlî tarafından izlenmekte olan Muhtâr zaman içerisinde onlara daha yakınlaşmıştır.

Mevâlî'nin Muhtâr'a son derece bağlı oldukları ve Muhtâr'ın yanında tüm güçleri ile ve her şeyi göze alarak savaştığı rivayet edilir. ${ }^{58}$ Watt'a göre, Arap olmayan unsurları kıyamında görevlendirerek mevâlîyi böylesi bir hadisenin içine dâhil etmekte Muhtâr, bir ilktir. ${ }^{59}$ Muhtâr'ın, hareketinde mevâlîye yer vermesinin mevâlîyi kendisinden sonraki birçok isyana karşı cesaretlendirdiği yorumu yapılmaktadır. ${ }^{60}$

Muhtâr'a katılan kimseler hakkında bilgi edinmek için şu hadiseye dikkat çekmek istiyoruz. 66/686 yılında Muhtâr Kûfe'yi ele geçirmişti. Şam orduları ile karşılaşmak üzere güçlerinin önemli bir kısmının şehirden ayrılmasını fırsat bilen eşraf, isyan etmeye karar verdi. İsyan hazırlıkları sürecinde eșraf, Abdurrahman b. Mihnef'e gitmiştir. Abdurrahman b. Mihnef'in eşrâfa söylediği sözler arasında Muhtâr'ın adamları hakkında kullandığı ifadeler dikkat çekmektedir. Ondan kendilerine katılmasını istediklerinde Abdurrahman b. Mihnef: "Bu işten vazgeçin. Ben, bölünmenizden ve ayrılığa düşmenizden korkuyorum. En kahramanlarınız, ata en iyi binenleriniz, falanca falanca kişiler Muhtâr'ın yanındadır. Ayrıca köleleriniz ve azatlılarınız da Muhtâr'la birliktedir. Hepsi aynı amaçla hareket etmektedir. Azatlılarınız ise size karşı düşmanlarınızdan daha çok kin duymaktadır. Hepsi size karşı Arapların kahramanlığıyla ve Acemlerin düşmanlık duygularıyla savaşacaklardır" demiştir.61

Muhtâr'ın mevâlîye karşı tutumunun Kûfe'deki hurucundan önce menfî olduğu ifade edilmekte ve bu durum, aşağıda bir özet olarak vereceğimiz rivayete dayandırılmaktadır. ${ }^{62}$

Mekke savunması esnasında Abdullah b. Zübeyr saflarında çarpışan Muhtâr, Mekke sokaklarından Şam ordusunu çıkardıktan sonra mübarezeye çıkmıştır. ${ }^{63}$ Bu mübarezede Muhtâr'ın bir kişi öldürdüğünden bahsedilir. ${ }^{64}$ Çarpışmadan sonra Muhtâr, arkadaşının siyahî, kendisinin beyaz bir Rum köleyi öldürmüş olduğunu öğrenince arkadaşına dönerek:

57 Dîneverî, el-Ahbâru't-tıvâl, 292; Taberî, Târîh, 6: 33; İbn Hazm, Cemheretü ensâbi'l-Arab, 397; İbnü'l-Esîr, el-Kâmil, 3: 301; İbn Kesîr, el-Bidâye, 8: 268.

58 Taberî, Târîh, 6: 25-26.

59 William M. Watt. İslâm Düşüncesinin Teşekkül Devri, trc. Ethem Ruhi Fığlalı (Ankara, 1981), 53-54.

60 Îman Ali bi'n-Nûr, Devru'l-mevâlî fî sükûtu'd-devleti'l-Emevî (41-132/ 661-750) (Libya: Câmiatü Gâriyunus, 2008), 143.

61 Taberî, Târîh, 6: 44-45; İbn A'sem, el-Fütûh, 6: 260-261; İbnü'l-Esîr, el-Kâmil, 3: 305.

62 Hind Gassân, Hareketü'l-Muhtâr b. Ebî Ubeyd es-Sekafí fíl'-Kûfe, 225.

63 Taberî, Târîh, 5: 576-577; Ebu'l-Arab, Muhammed b. Ahmed b. Temîm et-Temîmî, el-Mihan, thk. Ömer Süleyman el-Ukaylî (Riyad: Dâru'l-Ulûm, 1984/1404), 204.

64 Ebu'l-Arab, el-Mihan, 204. 
"Zannımca iki köleyi öldürdük. Yenilmiş olsaydık bize güvenenler ve bizlerin kabileleri bizleri ayıplarlardı. Bu ikisinin benim nazarımda iki köpekten farkı yoktur. Bundan sonra kim olduğunu bilmediğim birisiyle asla çarpışmaya çıkmayacağım" dediği kaydedilir.65 İlerleyen zamanlarda mevâlîden güç alan ve söylemlerinde mevâlî haklarının savunulmasının gerekliliğini vurgulayan birisinin bu sözleri sarf etmesi yadırganacak bir tutumdur. Ayrıca İbn Zübeyr, o esnada kendisine gelecek her yardıma muhtaç olduğu bir dönemdedir. Bundan dolayı ordusunda mevâlî ve köleler bulunmaktadır. Onların yanında böylesi cüretkâr sözler etmesi pek makul görünmemektedir.

Yukarıda da izah ettiğimiz üzere esasında Muhtâr'ın ordusundaki mevâlî sayısı Arap askerlere nispetle azdır. Buna rağmen bu hareketin mevâlî ile anılmasının nedeni Muhtâr'ın mevâlî söylemleri ve şehirde kendisine muhalif olan kesimin, onun mevâlî politikalarına yönelttiği eleştirileri olmalıdır. Zira o, mevâlînin durumunu düzeltmeye yönelik söylemlerde bulunmuştur. Mevâlî Hz. Ali döneminde olduğu gibi fey ve ata paylarının dağıtımında Arap halkla eşit tutulmuştur. ${ }^{66}$ Ayrıca Muhtâr'ın mevâlînin ata binmesine müsaade etmesi ${ }^{67}$ ve bazı özel görevlere mevâlîden olan kimseleri getirmesi ${ }^{68}$ buna eklenmelidir. Muhtâr'ın bu tasarruflarının mevcut sayısını arttırmaya yönelik olduğu anlaşılmaktadır. Şehir eşrafı ise Muhtâr'ın başta mevâliye karşı tutumu olmak üzere diğer bazı politikalarını gerekçe göstererek isyan etmiş̧9 ve Kûfe dışında yürüttükleri propaganda sürecinde Muhtâr yönetimine olan eleştirilerinin en başına onun mevâlî politikalarını yerleştirmişlerdir..$^{70}$ Mevâliye tanınan haklardan Muhtâr hareketinde olan bazı kimselerin de rahatsızlık

65 Taberî, Târîh, 5: 577.

66 Dineverî, el-Ahbâru't-tıvâl, 306; Taberî, Târîh, 6: 96; İbn Miskeveyh, Tecâribü'l-ümem, 2: 200; İbnü'l-Esîr, el-Kâmil, 3: 332. Mevâlînin atıyye dağıtımındaki konumu ile ilgili geniş bilgi için bk. Adnan Demircan, İslam Tarihinin İlk Döneminde Arap-Mevâlî İlişkisi, 45-48.

67 Taberî, Târîh, 6: 43-44; İbn A'sem, el-Fütûh, 6: 260; İbn Miskeveyh, Tecâribü'l-ümem, 2: 167169; İbnü'l-Esîr, el-Kâmil, 3: 304-305.

68 Taberî, Târîh, 6: 33; İbnü'l-Esîr, el-Kâmil, 3: 301. Muhtâr adlî işlerle ilgilenmesi için Kâdı Şureyh'i atamak istemiștir. Bu görevi çeșitli bahanelerle reddeden Kâdı Şureyh, mevâlîdendir. Bk. Belâzürî, Ensâb, 6: 395-396; Taberî, Târîh, 6: 34-35; İbn Kesîr, el-Bidâye, 8: 268.

69 Taberî, Târîh, 6: 43-44; İbn A'sem, el-Fütûh, 6: 260; İbn Miskeveyh, Tecâribü'l-ümem, 2: 167169; İbnü'l-Esîr, el-Kâmil, 3: 304-305.

70 Belâzürî, Ensâb, 6: 428; Dîneverî, el-Ahbâru't-tıvâl, 304; Taberî, Târîh, 6: 94.

70 Belâzürî, Ensâb, 6: 428; Dîneverî, el-Ahbâru't-tıvâl, 304-305; Taberî, Târîh, 6: 94. Muhtâr'ın mevâlîye tanıdığı özgür ortam kendi adamları tarafından da olumlu karşılanmamaktadır. Örneğin, Mezâr savaşında mevâlî süvariler, atlarından indirilerek piyade olarak savaşmaları sağlanmıș ve beklide savașı kaybetmelerine neden olan en büyük hatayı yapmışlardır. Bk. Dîneverî, el-Ahbâru't-tıvâl, 306; Taberî, Târîh, 6: 96; İbn Miskeveyh, Tecâribü'l-ümem, 2: 200; İbnü'l-Esîr, el-Kâmil, 3: 332. Geniş bilgi için bk. Yasin Kurnaz, Muhtâr b. Ebî Ubeyd esSekafínin Hayatı, Siyasî ve Askerî Faaliyetleri (1/622-67/687) (Doktora Tezi, Necmettin Erbakan Üniversitesi, 2018), 226-227. 
duyduğu görülmektedir. 67/687 yılında Basra'dan gelen Mus'ab b. Zübeyr güçleri ile çarpışacak orduda mevâlî atlı birliklerinden rahatsız olan Abdullah b. Vuheyb, ordu komutanı Ahmer b. Şumeyt'e mevâlîyi piyade olarak savaştırmasını telkin etmiştir. ${ }^{71}$ Mevâlînin savaştan kaçabileceği iddiasıyla ortaya attığı ve belki de savaşın kaybedilme sebebi olan bu kușku, esasında mevâlînin süvari olmasından duyulan rahatsızlıktan ibarettir. ${ }^{2}$ Muhtâr hareketinin mevâlî ile anılmasının bir diğer sebebi de Muhtâr öldürüldükten sonra Kûfe vali konağında muhasara edilen ve sayıları 3.000 ile 7.000 arasında zikredilen taraftarlarından büyük çoğunluğunun mevâlî olmasıdır. ${ }^{73}$

\section{KÛFE DIŞINDAN MUHTÂR'A DESTEK OLAN UNSURLAR}

Muhtâr hareketi esas itibariyle Kûfe şehrinin sınırları içersinde hayat bulmuştur. Bununla beraber sınırlı sayıda rivayetlerde Kûfe dışındaki bazı şehirlerde Muhtâr hareketine destek çıkıldığına dair bilgilere rastlanılmaktadır. İbnü’l-Cevzî’nin aktardığına göre Medâin bu şehirlerin başında gelmektedir. ${ }^{74}$ Ancak onun bu rivayetini teyit eden başka bir bilgi bulunmamaktadır. Muhtâr'ın Medâin'de yaşadığı, amcası Sa'd b. Mes'ûd'un orada bir dönem valilik yaptığı göz önünde bulundurulduğunda Medâin ile Kûfe arasındaki bu yakın temasın Muhtâr hareketine destek olmak üzere bazı kimselerin katılımını sağlaması neticesi, tabii görünmektedir. Ayrıca Kûfe'deki halktan bir kesiminin Medâin'e yerleștiği, Kûfe'ye gelip giderek Kûfe ile ticari ve siyasi ilişkilerini korumakla beraber Medâin'de yaşadığı bildirilmektedir. ${ }^{75}$ Kûfe ile Medâin arasındaki yakın ilișkiye bir diğer örnek Tevvâbîn hareketine Medâin'de sağlanan katılımdır76 ki bu durum iki şehir halkının birlikte hareket etme yönünü daha iyi anlamamızı sağlar. Bunlara rağmen Muhtâr'ın Medâin'de hareketine destek için bir davette bulunduğuna dair herhangi bir rivayetle karşılaşılmamaktadır. Ancak Muhtâr'ın böyle bir çağrıda bulunmuş olması muhtemeldir.

Bazı rivayetlere göre Basra'da da Muhtâr hareketine destek arandığı

71 Dîneverî, el-Ahbâru't-tıvâl, 306; Taberî, Târîh, 6: 96.

72 Geniş bilgi için bk. Yasin Kurnaz, Muhtâr b. Ebî Ubeyd es-Sekafî̀nin Hayatı, Siyasî ve Askerî Faaliyetleri (1/622-67/687), 225-226.

73 Belâzürî, Ensâb, 6: 445, 452; Dîneverî, el-Ahbâru't-tıvâl, 309; Taberî, Târîh, 6: 116; İbn Abdürabbih, Ebû Ömer Şihâbüddîn Ahmed b. Muhammed el-Endelüsî, el-İkdü'l-ferîd (Beyrut: Dâru'l-Kütübi'l-İlmiyye, 1404), 5: 154; Makdisî, Ebû Nasr Mutahhâr b. Tâhir, el-Bed ve't-târîh (by. y.y. ts.), 6: 23; Askerî, Ebû Hilâl el-Hasen b. Abdillâh b. Sehl, el-Evâil (Tanta: Dâru'l-Beșîr, 1408), 315; İbn Kesîr, el-Bidâye, 8: 320. Muhasara edilen bu kimselerin tamamı öldürülmüștür. Geniş bilgi için bk. Yasin Kurnaz, Muhtâr b. Ebî Ubeyd es-Sekafínnin Hayatı, Siyasî ve Askerî Faaliyetleri (1/622-67/687), 239-242.

74 Sibt İbnü'l-Cevzî, Ebu'l-Muzaffer Șemsüddîn b. Kızoğlu et-Türkî el-Avnî el-Bağdâdî, Tezkiretü havâssi'l-e'imme fî hasâ'isi'l-e'imme (Necef: el-Matbaatül-Haydariyye, 1964/1386), 283.

75 Taberî, Târîh, 5: 557.

76 Belâzürî, Ensâb, 6: 367. 
aktarılmaktadır. Basra'da yaşayan ve sıkı bir Ehl-i Beyt taraftarı olan Müsennâ b. Mahrebe tarafından bu ișin yürütüldügü anlașılmaktadır. Müsennâ b. Mahrebe Süleyman b. Surâd'la birlikte Tevvâbîn'e katılmış ve hezimete uğrayan Tevvâbîn ordusundan kalanlarla birlikte Kûfe'ye gelmiştir. Muhtâr'a gizlice bey'at etmiş, ona Basra'da faaliyet yürütmesini teklif etmiş ve Muhtâr'da buna izin vermiștir. Muhtâr henüz Kûfe'yi ele geçirmeden Basra'da çalışmalarını başlatmıştır. Kûfe'nin ele geçirilmesinde sonra Müsennâ Basra'da çalışmalarının yoğunluğunu arttırmıştır. Hatta burada bir mescit edindiği belirtilmektedir. Abdullah b. Zübeyr'e bağlı Basra valisi ise onun bu çalışmalarına kayıtsız kalamayarak Müsennâ'nın üzerine adamlarını göndermiş, çatışmada yenilen Müsennâ kendi kavmi olduğunu anladığımız Benî Abdilkays'a sığınmıştır. Basra valisi ile yapılan müzakereler neticesinde Müsennâ ve arkadaşlarının Kûfe'ye gitmelerine müsaade edilmiştir. Müsennâ Kûfe'ye gelince kendisini koruyan kabile liderleri hakkında övgüyle bahsetmiștir. Bunun üzerine Muhtâr onları bir mektupla hareketine katılmaya davet etmiştir. Onlar ise Muhtâr'ı ciddiye almamışlardır. ${ }^{77}$ Muhtâr'ın davetine verdikleri tepkiye bakıldığında onların, Müsennâ ve adamlarına sadece kabilevî duygularla yaklaştıkları anlaşılmaktadır. ${ }^{78}$ Muhtâr hareketine Basra'dan destek çıkılmamıș, Basra'dan gerçekleşen katılımlar bireysel girişimler olarak kalmıştır.

\section{SOSYO-EKONOMIIK BAKIMDAN ZAYIF OLAN KIIMSELER}

Muhtâr'ın, Kûfe'de faaliyetler yürütürken propagandasında kullandığı argümanlarından birisi de zayıf kimselerin savunulması ve korunmasıdır. İçerisinde kendilerini ifade edebileceklerini düşündükleri siyasal oluşumlarda yer alması tabii olan bu kesimler için de Muhtâr, kendi hareketinde bir yer açmıştır. Esasında Kûfe'deki bu kesimin siyasi olaylarda kendisini gösterdiği yeri, Sıffîn Savaşı olarak belirtebiliriz. Kûfe halkının Hz. Ali'ye Sıffîn Savaşı öncesinde yazdığı mektupta aralarında bu zayıf kimselere işaret edildiği zikredilmektedir. ${ }^{79}$

Muhtâr 61/680 yılında Emevî yönetim tarafından Kûfe'den sürülmüş 64/684 yılında tekrar Kûfe'ye dönmüştür. Sürgünden döndüğü zaman çeşitli kabilelerin ileri gelenleri ile yaptığı ön görüşmelerde kendisinin Muhammed b. Hanefiyye tarafından gönderildiğini ve Muhammed b.

77 Belâzürî, Ensâb, 5: 415-417; Taberî, Târîh, 6: 66-68.

78 Zehebî Muhtâr' ın faaliyetlerine destek aramak için Basra'ya bizzat kendisinin gittiğini, Hz. Hüseyin ve katillerini orada zikrettiğini ardından İbn Ziyâd tarafından yakalanarak 100 değnek cezasına çarptırıldığını ve Tâif'e sürüldüğünü söylemektedir. Bk. Ebû Abdillâh Şemsüddîn Muhammed b. Ahmed b. Osmân et-Türkmânî el-Fârikî ed-Dimaşkî ez-Zehebî, Siyeru a'lâmi'n-nübelâ, thk. Şuayb Arnâût (b.y. Müessesetü'r-Risâle, 1980/1405), 4: 507. Anlaşıldığına göre Zehebî, Muhtâr'ın Müslim b. Akîl'e destek vermesi neticesinde Kûfe'den sürülmesi hadisesi ile yukarıda zikredilen olayı karıștırmıștır. Bk. Belâzürî, Ensâb, 5: 385; Taberî, Târîh, 5: 571.

79 Taberî, Târîh, 5: 79. 
Hanefiyye'nin kendisine işgalcilerle ve mülhidlerle çarpışmayı, Ehl-i Beyt'in $^{80}$ temiz kanını akıtanlardan intikam almayı, zalimleri ezilenlerin üzerinden uzaklaştırmayı emrettiğini söylemiştir. ${ }^{81}$ Temel amaçlarından birisi olarak ilk etapta ortaya koyduğu birkaç hareket noktasından birisinin toplumda var olan ve zayıf kimseler olarak adlandırlabilecek kesimi kendi yanına çekme girişimi olarak göze çarpmaktadır. Yine Muhtâr, Kufe'yi ele geçirdiği gecenin sabahında, üzerine bey'at aldığı konulardan bir tanesini de zayıfları korumak olarak tayin etmiştir. ${ }^{82}$ Kûfe'de böyle bir zayıf kesimin varlığı ve Muhtâr'ın onları koruyacağına söz vererek Hz. Hüseyin'in intikamını almak için onları örgütlediği anlaşılmaktadır. ${ }^{83}$

Hind Gassân Kitâbü'l-Ahdâs'tan naklen Mustazafların Emevîler döneminde Kûfe yöresinde başka bir anlam kazandığını, Ehl-i Beyt taraftarlarının sırf Hz. Ali taraftarı oldukları için Emevî idarecilerin kendilerini dîvan listelerinden çıkarmalarından korktuklarını, dolayısıyla böyle bir uygulamanın varlığı münasebetiyle Mustazaf kavramının Ehl-i Beyt taraftarlarına müteallik olduğunu söyler. Bu kesime ilaveten toprak işçisi olup iktisadi durumları kötü olan kimselerin varlığını da inkâr etmez. ${ }^{84}$ Hakikaten Muhtâr döneminde ekonomik ve sosyal zayıflıkları itibariyle bu harekete katılmış kimselerden birinin adını tam olarak zikretme imkânı görülmemektedir. Bu itibarla Hind Gassân'ın yorumu haklılık kazanmaktadır. Ancak her sosyal-siyasal harekette olduğu gibi, yaşam şartları itibariyle hayatından memnun olmayıp Muhtâr hareketinde kendini ifade etme imkânını hisseden bazı mutsuz kesimlerin var olma ihtimali yok sayılmamalıdır. Zayıf kimseler denince akla Arap olmayan mevâlîden müteşekkil zayıf kimseler gelmemelidir.

Kûfe'deki bütün mustazafların Muhtâr saflarında kendisini ifade edebildiğini söylememiz ise mümkün değildir. Zira Ubeydullah b. el-Hurr Muhtâr öldürüldükten sonra köle ve mevâlîler hakkında ne yapılacağı tartışılırken bu kimselerin öldürülmemesini onların bir kısmının Muhtâr hareketine katılmayan zayıf kimselere verilebileceğini teklif etmektedir. Ubeydullâh b. el-Hurr'un Mus'ab tarafından dikkate alınmayan bu tekli-

80 Ehl-i Beyt ibaresi hakkında kavram olarak geniş değerlendirmeler için bk. Mehmed Bahaüddin Varol, Ehl-i Beyt Kavramsal Boyut (Konya: Yediveren Yayınlarl, 2004.)

81 Belâzürî, Ensâb, 6: 379-380; Taberî, Târîh, 5: 578-580; İbn A'sem, el-Fütûh, 6: 207-208; İbn Miskeveyh, Tecâribü'l-ümem, 2: 110; İbn Kesîr, el-Bidâye, 8: 248; Mustafa Asım Köksal, Hz. Hüseyin ve Kerbelâ Faciası (İstanbul: Köksal Yayıncıllk, ts.), 300-301.

82 Taberî, Târîh, 6: 31-32; İbnü’l-Esîr, el-Kâmil, 3: 300-301; İbn Kesîr, el-Bidâye, 8: 267-268. İbn A'sem Muhtâr'a ait daha uzun ve daha beliğ bir konuşma aktarır. Bk. İbn A'sem, el-Fütûh, 6: 240-241.

83 İbn A'sem, el-Fütûh, 6: 225, 240.

84 Hind Gassân, Hareketü'l-Muhtâr b. Ebî Ubeyd es-Sekafí fíl-Kûfe, 223. İbn A'sem Muhtâr'in Kûfe'yi ele geçirdikten sonra yaptığı konușmasında onun Ehl-i beytten ve Ehl-i Beyt taraftarlarından zayıf konumda bulunanları korumanın siyasi ilkelerinden birisi olduğunu vurguladığını aktarmaktadır. İbn A'sem, el-Fütûh, 6: 240. 
finden Kûfe'deki muhalif kanatta da zayıf kimselerin varlığı anlaşılmaktadir. 85

Eşrâfın Muhtâr'a karşı çıkarttığı isyanın bastırılmasından sonra idam edilme vaktini beklemesi için hapse gönderilen Sürakâ b. Mirdâs Muhtâr'ın karşısına çıkınca, kurtulmak için Muhtâr'a okuduğu şiirinde Muhtâr ve adamlarının zayıf kimselerden olduklarını düşündüklerinden dolayı ne kadar büyük bir hata ettiğini ifade etmiştir. ${ }^{86}$ Muhtâr ve adamlarının muhalif olan kimseler tarafından nasıl tanımlandığını anlamamızı bir açıdan izah etmektedir.

\section{ZENCÎLER}

Muhtâr'ın taraftar kitlesini anlamaya çalıştığımız bu çalışmamızda karşımıza bir rivayette çıkan Zencî unsurunu da belirtmeliyiz. Yalnızca Ebû Hilal el-Askerînnin kaydettiği rivayette "Muhtâr Zencîleri (Zenci) sevdi. İşlerini onların üzerine bina etti ve kölelerin kalbini fethetti" denilmektedir. ${ }^{87}$ Sayıca az kalan ve ekonomik ve sosyal bakımdan kendisini zayıf hisseden bir kesim olarak bu kıyamda yer almış olabilir. Bölgedeki köle istihdamının fazlalılığı nedeniyle ilerleyen yıllarda daha fazla tarih sahnesinde yer alacak olan zencîlerin bölgedeki birçok isyana destek vermiş olmaları, Muhtâr es-Sekafî hareketinin de bunlardan birisi olması ${ }^{88}$ mümkündür. Ancak diğer kaynaklarda, Ebû Hilal el-Askerî'nin kaydettiği rivayeti doğrulayabilecek ya da destekleyebilecek herhangi bir bilgiye rastlanılmamaktadır.

\section{SONUÇ}

66-67/685-687 yılları arasında Kûfe'de iktidarı ele geçiren Muhtâr, Hz. Hüseyin'in şehit edilmesinin intikamını almak üzere propaganda geliştirmiştir. Aynı söylemlerle hareket eden Süleyman b. Surâd hareketinin mağlubiyetine rağmen Muhtâr başarıya ulaşmıştır. Bunun en önemli sebebi Muhtâr'ın birden fazla politik davranış sergilemesidir. Zira Tevvâbîn hareketinin neredeyse tek propagandası Kerbelâ'nın intikamını almak iken Muhtâr buna zayıfları korumayı, mevâlî haklarını savunmayı, hatta kendisine katılacak tüm köleleri azat edeceğini eklemek suretiyle başarıya ulaşmıştır. Muhtâr hareketinin taban kitlesi üzerine gerçekleştirdiğimiz çalışmamızda bazı noktalar göze çarpmaktadır. Muhtâr'ın kıyamına katılan kabileler Yemenî kabilelerdir. Bu kabilelerin önceden beri Kuzey

85 Taberî, Târîh, 6: 116.

86 Taberî, Târîh, 6: 54; İbn A'sem, el-Fütûh, 6: 264; İbn Miskeveyh, Tecâribü'l-ümem, 2: 178; İbnü'l-Esîr, el-Kâmil, 3: 310; Hind Gassân, Hareketü'l-Muhtâr b. Ebî Ubeyd es-Sekafî fîll-Kûfe, 223.

87 el-Askerî, el-Evâil, 312.

88 Mustafa Demirci, Siyah Öfke Ortaçağ İslâm Dünyasında Zenci Kölelerin İsyanı (869-883), 2. Baskı (Konya: Çizgi Kitabevi, 2017), 86. 
kabileleri ile sorunları bulunmaktadır. Baştan beri politik tercihleri itibariyle farklı görüşlere sahip bu kesimler, karşı hissettikleri cenahta bir toplanma eğilimine çok çeşitli sebeplerden dolayı sahiptirler. Kuzey Araplarından olan kabilelerden bazılarının da bu harekette görev aldıklarını görmekle birlikte bu durumun daha çok bireysel kaldı̆̆ı göze çarpmaktadır. Örneğin Muhtâr, Kuzey Araplarından olan Sakîf kabilesindendir. Oysa Sakîf kabilesi genel itibariyle Emevî saflarında yer alan Kays-Aylân kabilesinin bir koludur. Ancak Muhtâr Kûfe'de değil, Medâin'de yaşamaktadır ve $\mathrm{Hz}$ Ali'nin valisi olan amcasının yanında yetişmiştir. Bu durumun onun tercihine etkisi olduğu kanaati hâsıl olmaktadır. Onun, kabilesinden gördüğü desteğin bireysel kalması, Emevî valisi Ubeydullah b. Ziyâd'dan işkence gören Muhtâr'ın, Emevî düşmanlığını kişiselleştirdiği yorumunu haklı çıkarır niteliktedir.

Muhtâr'a katılan kesimlerden bir tanesi de mevâlîdir. Muhtâr'ın mevâlîye fey ve atâdan hisse vermesi, onların ata binmelerine müsaade etmesi, hatta kendisi için çalışan özel atlı muhafız birliği oluşturması sayılarının artmasını sağlamıştır. Yine de el-Mezâr savaşına kadar mevâlîden müteşekkil bir bölük kurulduğunu söylemek zordur. Arap kabilelerin asker sayısına oranla mevâlî sayısı az kalmaktadır. Buna rağmen Muhtâr'ın mevâlî ile birlikte anılmasında sebep, eşrâfın Muhtâr'ın mevâlî politikalarına getirdiği eleştiriler olmalıdır.

Muhtâr'ı diğer Ehl-i Beyt yanlısı hareketlerden ayıran bir diğer söylemi ise onun sosyo-ekonomik bakımdan zayıf olan kimseleri koruma va'didir. Bu propagandanın Ehl-i Beyt yanlılarının Emevî yönetimden ayrımcılığa maruz kalanların kastedildiği yorumu yapılmaktadır. Ancak biz bu politikanın, Muhtâr'ın taraftar sayısını arttırmak için tüm zayıf kesimlere yönelik bir çağrısı olduğu ve bu çağrıya şehirdeki sosyo-ekonomik bakımdan zayıf olanların çoğunun katıldığı kanaatindeyiz. Muhtâr'a Kûfe'nin haricinde Medâin'den de katılım gerçekleşmiştir. Basra'dan ise umduğu desteği bulduğunu söylemek güçtür.

\section{KAYNAKÇA}

Alûsî, Ebü'l-Meâli Cemâleddin Mahmûd Şükrî. Bulûğu'l-ereb fî ma'rifeti ahvâl'l-Arab.

Thk. Muhammed Behcet el-Eserî. Mısır: Dâru'l-Kütübi'l-Mısrî, 2012.

Askerî, Ebû Hilâl el-Hasen b. Abdillâh b. Sehl. el-Evâil. Tanta: Dâru'l-Beşîr, 1408.

Bağdâdî, Ebû Mansûr Abdülkahir b. Tâhir b. Muhammed et-Temîmî el-Bağdâdî. el-

Fark beyne'l-fırak ve beyâni'l-firkati'n-nâciye. Beyrut: Dâru'l-Âfâki'l-Cedîde, $1977 / 1397$.

Belâzürî, Ebü'l-Abbas Ahmed b. Yahyâ b. Câbir. Ensâbu'l-eșrâf. Thk. Suheyl ZekkârRiyad Ziriklî. 13 Cilt. Beyrut: Dâru'l-Fikr, 1996/1417.

Demircan, Adnan. İslâm Tarihinin İlk Döneminde Arap-Mevali İlişkisi. İstanbul: Beyan Yayıncilık, 2015. 
Demirci, Mustafa. Siyah Öfke Ortaçağ İslâm Dünyasında Zenci Kölelerin İsyanı (869883). 2. Baskı. Konya: Çizgi Kitabevi, 2017.

Dîneverî, Ebû Hanîfe Ahmed b. Dâvûd ed-Dîneverî. el-Ahbâru't-tıvâl. Thk. Abdülmün'im Âmir. Kahire: Dâru İhyâi'l-Kütübi'l-Arabî, 1960.

Ebü'l-Arab, Muhammed b. Ahmed b. Temîm et-Temîmî. el-Mihan. Thk. Ömer Süleyman el-Ukaylî. Riyad: Dâru'l-Ulûm, 1984/1404.

Ebü'l-Fazl Cemâlüddîn Muhammed b. Mükerrem b. Ali. Lisânü'l-mîzân. Beyrut: Dâr Sâdır, 1994/1414.

Erul, Bünyamin. "Semûre b. Cündeb”. DİA. 36: 501-502. Ankara: TDV Yayınları, 2009.

Hemdânî, Ebû Muhammed Lisânü'l-Yemen el-Hasen b. Ahmed b. Ya'kûb. el-İklîl. b.y.: y.y., ts.

Hind Gassân Ebü'ș-Şa'r. Hareketü'l-Muhtâr b. Ebî Ubeyd es-Sekafî fi'l-Kûfe. Amman: Câmiatü'l-Ürdüniyye, 1983.

İbn Abdürabbih, Ebû Ömer Şihâbüddîn Ahmed b. Muhammed el-Endelüsî. el-İkdü'lferîd. Beyrut: Dâru'l-Kütübi'l-İlmiyye, 1404.

İbn A'sem, Ebû Muhammed, Ahmed b. Muhammed b. Ali el-Kûfî. el-Fütûh. Thk. Ali Şîrî. 9 Cilt. Beyrut: Dâru'l-Edvâ, 1991/1411.

İbn Asâkir, Ebü'l-Kâsım Ali b. Hasen b. Hibetullâh b. Hüseyn. Târîhu Dımeșk. Thk. Amr b. Ğarâme el-Amrî. Beyrut: Dâru'l-Fikr, 1995/1415.

İbn Hazm, Ebû Muhammed Ali b. Ahmed b. Saîd el-Endelüsî el-Kurtubî. Cemheretü ensâbi'l-Arab. Thk. Komisyon. Beyrut: Dâru'l-Kütübi'l-İlmiyye, 1983/1403.

İbn Kesîr, Ebü'l-Fidâ İsmâîl b. Ömer. el-Bidâye ve'n-nihâye 15 Cilt. Beyrut: Dâru'lFikr, 1986/1407.

İbn Miskeveyh, Ebû Alî Ahmed b. Muhammed b. Ya'kūb el-Hâzin. Tecâribü'l-ümem ve teâkibü'l-himem. Thk. Ebü'l-Kâsım İmâmî. 7 Cilt. İran: Serveş, 2000.

İbnü'l-Cevzî, Cemâlüddîn Ebü'l-Ferec Abdurrahmân b. Ali b. Muhammed. elMuntazam fî târîhi'l-ümem ve'l-mülûk. thk. Muhammed Abdülkādir Atâ, Mustafâ Abdülkādir Atâ. 19 Cilt. Beyrut: Dâru'l-Kütübi'l-İlmiyye 1992/1412.

İbnü'l-Esîr, İzzüddîn b. Ebi'l-Hasen Ali b. Ebi'l-Kerem Muhammed b. Muhammed elCezerî. el-Kâmil fîtt-târîh. Thk. Ömer Abdüsselâm Tedmürî. 10 Cilt. Beyrut: Dâru'l-Kütübi'l-Arabî, 1997/1417.

Îman Ali bi'n-Nûr. Devru'l-mevâlî fî sükûtü'd-devleti'l-Ümevî (41-132/ 661-750). Libya: Câmiatü Gâriyunus, 2008.

Kehhâle, Ömer Rıza. Mu'cemü'l-kabâili'l-Arabi'l-kadîme ve'l-hadîse. 5 Cilt. Beyrut: Müessesetü'r-Risâle, 1994/1414.

Kurnaz, Yasin. Muhtâr b. Ebî Ubeyd es-Sekafî’nin Hayatı, Siyasî ve Askerî Faaliyetleri. Doktora Tezi, Necmettin Erbakan Üniversitesi, 2018.

Köksal, Mustafa Âsım. Hz. Hüseyin ve Kerbelâ Faciası. İstanbul: Köksal Yayıncılık, ts.

Makdisî, Ebû Nasr Mutahhâr b. Tâhir. el-Bed ve't-târîh. b.y.: y.y., ts.

Nüveyrî, Şihâbüddîn Ahmed b. Abdilvehhâb b. Muhammed b. Abdiddâim el-Kuraşî. Nihâyetü'l-ereb fî̀ fünûni'l-edeb. 33 Cilt. Kahire: Dâru'l-Kütübi ve'l-Vesâiki'lKavmî, 2002/1423.

Reckondorf. "Ezd”. İA. 4: 430. İstanbul: MEB Basımevi, 1987.

Sıbt İbnü'l-Cevzî, Ebü'l-Muzaffer Şemsüddîn b. Kızoğlu et-Türkî el-Avnî el-Bağdâdî. Tezkiretü havâssı'l-e'imme fî hasâ'isi'l-e'imme. Necef: el-Matbaatü'lHaydariyye, 1964/1386.

Söylemez, Mehmet Mahfuz. Kûfe'nin Siyasi Tarihi. Ankara: Ankara Okulu Yayıncılık, 2015.

Taberî, Ebû Câfer Muhammed b. Cerîr. Târîhu't-Taberî, Târîhu'r-rusûl ve'l-mülûk. 11 Cilt. Beyrut: Dâru't-Türâs, 1967/1387. 
Varol, Mehmed Bahaüddin. Ehl-i Beyt Kavramsal Boyut. Konya: Yediveren Yayınları, 2004.

Varol, Mehmet Bahaüddin. Siyasallaşma Sürecinde Ehl-i Beyt. Konya: Yediveren Yayınları, 2004.

Watt, William M. İslâm Düşüncesinin Teșekkül Devri. Trc. Ethem Ruhi Fığlalı. Ankara: 1981.

Yiğit, İsmail. "Mevâlî”. DİA. 29: 424-426. Ankara: TDV Yayıncllık, 2004.

Zehebî, Ebû Abdillâh Şemsüddîn Muhammed b. Ahmed et-Türkmânî el-Fârikî edDımaşkī. Siyeru a'lâmi'n-nübelâ. Thk. Şuayb Arnaûd, 25 Cilt. b.y.: Müessesetü'rRisâle, 1985/1405. 